\title{
EFFECT OF OCTREOTIDE ON ACUTE PANCREATITIS PATIENTS IN KOLKATA, INDIA: A RANDOMIZED CONTROLLED TRIAL
}

\author{
Minhajuddin Khurram¹, Anindita Bhar², Debashis Bhattacharya3 ${ }^{3}$ Mohamed Siddiq4, Yusuf Zai Manzar Khan ${ }^{5}$ \\ ${ }^{1}$ Senior Resident, Department of Surgery, K.P.C. Medical College and Hospital, Kolkata, West Bengal, India. \\ ${ }^{2}$ Assistant Professor, Department of Surgery, K.P.C. Medical College and Hospital, Kolkata, West Bengal, India. \\ 3 Professor, Department of Surgery, K.P.C. Medical College and Hospital, Kolkata, West Bengal, India. \\ ${ }_{4}^{4}$ Associate Professor, Department of Physiology, Al Ameen Medical College, Bijapur. \\ 5 Post Graduate, Department of Surgery, Al Ameen Medical College, Bijapur.
}

\section{ABSTRACT}

\section{BACKGROUND}

Acute pancreatitis is the final result of premature pancreatic pro-enzyme activation leading to "auto digestion" of the parenchyma, thereby inducing a cascade of inflammatory response which further damages the organ. Theoretically inhibition of pancreatic secretion may prove useful in management of acute pancreatitis. There are evidences that somatostatin and octreotide apart from having inhibitory effect on pancreatic secretion also has some cytoprotective properties and that they counter the ileus and bacterial translocation in acute pancreatitis.

\section{OBJECTIVE}

The study was aimed at assessing the effect of octreotide on acute pancreatitis in the study area.

\section{MATERIALS AND METHODS}

Twenty six patients admitted with diagnosis of acute pancreatitis $(\mathrm{n}=26)$ were randomized into two groups. Group I acted as control, while Group II received $200 \mu \mathrm{g}$ of subcutaneous octreotide thrice daily for a period of first 10 days post admission.

\section{RESULTS}

Positive treatment values with less complication rates were seen on treatment with octreotide in Group II.

\section{CONCLUSION}

Octreotide may be a useful addition in the otherwise conservative management of acute pancreatitis.

\section{KEYWORDS}

Acute Pancreatitis, Somatostatin, Octreotide.

HOW TO CITE THIS ARTICLE: Khurram M, Bhar A, Bhattacharya D, et al. Effect of octreotide on acute pancreatitis patients in Kolkata, India: a randomized controlled trial. J. Evolution Med. Dent. Sci. 2016;5(42):2578-2580, D0I: 10.14260/jemds/2016/603

\section{INTRODUCTION}

Acute pancreatitis is a potentially lethal disease with a spectrum of severity which may range from mild self-limiting course, responding well to conservative management ${ }^{1,2}$ to severe illness with multi-organ failure and death. The pathophysiology of the disease is not fully understood and is believed to be the final result of premature pro-enzyme activation inside the pancreatic acinar cells. Co-localisation of zymogen granules and lysosomes occur within the acinar cells and is seen in minutes of pancreatic injury. 3 This premature activation causes "auto-digestion" of the pancreas with the resultant release of pro-inflammatory, antiinflammatory, reactive oxygen and chemotactic mediators. The net result is an inflammatory response which may lead to major systemic and metabolic complications if such mediators, toxins and vasoactive substances access the systemic circulation.4,5 and may lead to multi-organ dysfunction syndrome and death.6-8

\section{Financial or Other, Competing Interest: None.}

Submission 12-04-2016, Peer Review 05-05-2016,

Acceptance 13-05-2016, Published 25-05-2016.

Corresponding Author:

Dr. Minhajuddin Khurram,

Senior Resident, Department of Surgery,

K.P.C. Medical College and Hospital,

Kolkata, West Bengal, India.

E-mail: dr.khurram.minhaj@gmail.com

DOI: $10.14260 /$ jemds/2016/603
At present the major problem is lack of a specific drug for the treatment of acute pancreatitis. The current standard of care is admission in an intensive care unit and symptomatic treatment. $4-8$

It is known that during the course of the disease, further endogenous induction of pancreatic secretion by enteral nutrition worsens the acute inflammation; hence, one of the basic principles of conservative management is avoidance of enteral feeding and nasogastric suctioning. Since the basic pathology behind acute pancreatitis is "auto-digestion," it has been theorised that inhibition of pancreatic enzyme secretion may slow down the auto-digestion of the pancreatic parenchyma and hence may affect the prognosis.

Studies with somatostatin and analogues for pancreatic secretion inhibition began in the early 1980s for the treatment of acute pancreatitis.9-12 Limberg and Kommerell.13 in 1980 used somatostatin for the treatment of acute pancreatitis and it stated "an impressive clinical improvement in all patients." On the other hand other studies with somatostatin. ${ }^{10-12}$ and its analogues. ${ }^{14-16}$ showed contradictory results that they have no beneficial effect in the treatment. With a strong pathophysiological basis, yet conflicting results with somatostatin and its analogue in the management of acute pancreatitis, we set forth with the current study to see the effect of octreotide in acute pancreatitis patients of Kolkata, India. 


\section{MATERIALS AND METHODS}

We evaluated the effect of octreotide on the course of acute pancreatitis. International guidelines were used as dictated by Tenner $\mathrm{S}$ et $\mathrm{al}^{17}$ and Banks PA et $\mathrm{al}^{18}$ for the diagnosis of acute pancreatitis. Adult patients having only moderate-tosevere pancreatitis with no co-morbidities were included in the study.

Twenty six patients with acute pancreatitis $(n=26)$ were randomised into two groups of 13 each. Both the groups received the same treatment protocol. Group I acted as control, while Group II also received $200 \mu \mathrm{g}$ of subcutaneous octreotide thrice daily for a period of 10 days post admission.

The effect of treatment was calculated using a standard scoring system (See Table 1). ${ }^{19,20}$ in which complications were scored on admission and within 30 days. A positive difference in scores indicates a positive treatment effect and reduced complication rate. The results were then put to statistical consideration using paired ' $\mathrm{t}$ ' test.

\begin{tabular}{|c|c|c|c|}
\hline $\begin{array}{c}\text { Organ } \\
\text { Complications }\end{array}$ & Points & $\begin{array}{c}\text { Metabolic } \\
\text { Complications }\end{array}$ & Points \\
\hline Shock & 4 & Hypocalcaemia & 2 \\
\hline Sepsis & 4 & Clotting Disorders & 2 \\
\hline $\begin{array}{c}\text { Pulmonary } \\
\text { insufficiency }\end{array}$ & 3 & Jaundice & 1 \\
\hline Renal insufficiency & 3 & Hyperglycaemia & 1 \\
\hline Peritonitis & 3 & Encephalopathy & 1 \\
\hline Haemorrhage & 3 & Metabolic acidosis & 1 \\
\hline Ileus/subileus & 1 & $\begin{array}{c}\text { Death } \\
\text { (within 90 days) }\end{array}$ & 1 \\
\hline \multicolumn{4}{|c|}{ Table 1: Score System in Patients } \\
with Acute Pancreatitis
\end{tabular}

Approval was obtained from the Institutional Ethical Committee, K.P.C. Medical College and Hospital, Kolkata, India, prior to the commencement of the study. Treatment of patients was in accordance with all patient protection codes of ethics. Written informed consent was obtained from each patient.

\section{RESULTS}

The two groups were comparable in terms of age, gender and severity of pancreatitis (Table 2). The mean age of the control group (Group I) was $43.46 \pm 10.61$ years consisting of 9 males and 4 females and that of octreotide treated (Group II) was $44.23 \pm 12.59$ years having 7 males and 6 females. The mean Ranson's score of the octreotide treated group was $3.23 \pm 0.59$ and mean APACHE II (Acute Physiology and Chronic Health Evaluation II) score was $8.15 \pm 0.98$; meanwhile the respective scores for the control group were $3.15 \pm 0.68$ and $8.07 \pm 0.95$.

\begin{tabular}{|c|c|c|c|c|c|c|}
\hline \multirow{2}{*}{$\begin{array}{l}\text { Treat- } \\
\text { ment } \\
\text { Group }\end{array}$} & \multirow{2}{*}{$\begin{array}{l}\text { No. of } \\
\text { Patients } \\
\text { (n) }\end{array}$} & \multirow{2}{*}{$\begin{array}{c}\text { Mean } \\
\text { Age } \\
\text { (In } \\
\text { Years) }\end{array}$} & \multicolumn{2}{|c|}{$\begin{array}{c}\text { Gender } \\
\text { Distribution }\end{array}$} & \multicolumn{2}{|c|}{$\begin{array}{l}\text { Severity of } \\
\text { Pancreatitis } \\
\text { (Mean Scores) }\end{array}$} \\
\hline & & & \begin{tabular}{|c|} 
Males \\
(n)
\end{tabular} & $\begin{array}{c}\text { Females } \\
\text { (n) }\end{array}$ & \begin{tabular}{|} 
Ranson's \\
Score
\end{tabular} & $\begin{array}{l}\text { APACHE } \\
\text { II score }\end{array}$ \\
\hline $\begin{array}{c}\text { Group I } \\
\text { (Control) } \\
\end{array}$ & 13 & $\begin{array}{c}43.46 \pm \\
10.61 \\
\end{array}$ & 9 & 4 & \begin{tabular}{|c|}
$3.15 \pm$ \\
0.68 \\
\end{tabular} & $\begin{array}{c}8.07 \pm \\
0.95 \\
\end{array}$ \\
\hline $\begin{array}{l}\text { Group II } \\
\text { (Octreotide, } \\
3 \times 200 \mu \mathrm{g})\end{array}$ & 13 & $\begin{array}{l}44.23 \pm \\
12.59\end{array}$ & 7 & 6 & $\begin{array}{c}3.23 \pm \\
0.59\end{array}$ & $\begin{array}{c}8.15 \pm \\
0.98\end{array}$ \\
\hline \multicolumn{7}{|c|}{$\begin{array}{c}\text { Table 2: Comparison of Mean Age, Gender Distribution } \\
\text { and Mean of Ranson's Scores and APACHE II Scores } \\
\text { between the Test and the Control Groups }\end{array}$} \\
\hline
\end{tabular}

APACHE II: Acute Physiology and Chronic Health Evaluation II.
The difference of the scores on admission and within thirty days was positive in the octreotide treated group (Group II), the value being +1.762 , while that of the control group (Group I) was -2.0. These results were found to be statistically significant difference with $\mathrm{p}<0.05$ (Table 3 ).

\begin{tabular}{|c|c|c|c|}
\hline $\begin{array}{l}\text { Treatment } \\
\text { Group }\end{array}$ & $\begin{array}{l}\text { Admission } \\
\text { Score }\end{array}$ & $\begin{array}{l}\text { Follow-up } \\
\text { Score }\end{array}$ & $\begin{array}{c}\text { Difference } \\
\text { of Mean }\end{array}$ \\
\hline $\begin{array}{c}\text { Group I } \\
\text { (Control) }\end{array}$ & $5.15 \pm 1.34$ & $7.15 \pm 1.67$ & -2.0 \\
\hline $\begin{array}{l}\text { Group II } \\
\text { (Octreotide, } \\
3 \mathrm{X} 200 \mu \mathrm{g})\end{array}$ & $5.30 \pm 1.03$ & $3.538 \pm 1.12^{*}$ & +1.762 \\
\hline \multicolumn{4}{|c|}{$\begin{array}{c}\text { Table 3: Effect of Octreotide on Acute } \\
\text { Pancreatitis Patients in Study Area }\end{array}$} \\
\hline
\end{tabular}

Paired ' $\mathrm{t}$ ' test was done. Asterisks '*' showing statistically significant difference with $\mathrm{p}<0.05$.

\section{DISCUSSION}

The complete pathophysiology behind acute pancreatitis is not fully understood, but the final step in the disease process is activation of the pancreatic enzymes within the parenchyma leading to "auto-digestion" and invoking an inflammatory response, which further damages the pancreas. Endogenous somatostatin is produced by the gastric and pancreatic islet D cells and is popularly known as "universal off" switch. ${ }^{3}$ one of its actions being inhibition of secretion of pancreatic enzymes. Octreotide is a synthetic analogue of endogenous somatostatin. Upon the theory that inhibition of pancreatic secretion may be beneficial in acute pancreatitis, researches began in early 1980s with conflicting reports. ${ }^{10,11,14-16,21-23}$ Choi et al ${ }^{10}$ saw a "beneficial local effect" and remarked that "local inflammation was supressed by somatostatin treatment." Even when better clinical outcomes were seen, the results failed to prove a statistical significance. A meta-analysis done by Carballo et al 24 included some of these studies and proved a statistical significant outcome with somatostatin treatment.

For the optimum dose of octreotide, a study was conducted by Binder $\mathrm{M}$ et $\mathrm{al}^{20}$ with three different dosages of subcutaneous octreotide and results were interpreted according to the scoring system also used by us. 19,20 Though the results had no statistical power, yet the lowest complication rate was seen lowest with $200 \mu \mathrm{g}$ of subcutaneous octreotide thrice daily for 10 days (Table 4).

\begin{tabular}{|c|c|c|c|}
\hline $\begin{array}{c}\text { Treatment } \\
\text { Group }\end{array}$ & $\begin{array}{c}\text { Admission } \\
\text { Score }\end{array}$ & $\begin{array}{c}\text { Follow-up } \\
\text { Score }\end{array}$ & Difference \\
\hline Control & 5.1 & 7.2 & -2.1 \\
\hline $3 \times 100 \mu \mathrm{g}$ & 5.6 & 7.1 & -1.5 \\
\hline $3 \times 200 \mu \mathrm{g}$ & 5.0 & 2.0 & +3.0 \\
\hline $3 \times 500 \mu \mathrm{g}$ & 5.8 & 4.8 & +1.0 \\
\hline
\end{tabular}

Table 4: Results from the Study of Binder M et al ${ }^{20}$

Toskes PP et $\mathrm{al}^{25}$ saw the greatest pain relief in chronic pancreatitis with $200 \mu \mathrm{g}$ tid dose. Though the study was conducted for chronic pancreatitis, it could be extracted from it that $200 \mu \mathrm{g}$ tid dose serves as the optimum dose for clinical outcome.

The mechanism of action of somatostatin and its analogue probably is more than just secretion inhibition. Schwedes et al $^{26}$ induced acute pancreatitis in dogs and found considerable less inflammatory damage to the pancreas in animals treated with somatostatin. The "cytoprotective" 
effect of somatostatin was assumed to be the cause. Jenkins et al ${ }^{27}$ showed the cyto-protective effects of somatostatin and octreotide, in that he recorded increased hepatic and splenic reticulo-endothelial system activity and significantly reduced endotoxin concentration in serum with somatostatin and octreotide treatment.

Octreotide has also been proposed to counter the ileus seen during acute pancreatitis. Hui Zhou et al concluded "The pathogenesis of ileus in the early stage of Acute Necrotising Pancreatitis may be related to the neuropathy of the enteric nervous system. Octreotide may reduce the severity of ileus by lessening the damage to enteric motor innervation." 28 Another study by Guler 0 et al showed that in acute pancreatitis administering octreotide reduces bacterial translocation by preventing mucosal damage. 29

The ground for octreotide treatment in acute pancreatitis is strong with a logical physiological basis of mechanism by inhibition of secretion with studies showing its cytoprotective mechanisms and potential to reduce ileus and bacterial translocation; yet further studies with larger sample sizes are needed to solidify its efficacy.

\section{CONCLUSION}

Octreotide may be a useful addition in the management of acute pancreatitis, a disease with few other medical options. Further larger studies would be useful to better characterise the role of Octreotide in the management of acute pancreatitis.

\section{REFERENCES}

1. Beger HG, Bulchler M, eds. Acute pancreatitis. Research and clinical management. Berlin, Heidelberg, New York: Springer-Verlag 1987.

2. Buchler M. Objectification of the severity of acute pancreatitis. Hepatogastroenterology 1991;38(2):101-8.

3. Rhoads JE. Textbook of surgery: the biological basis of modern surgical practice. Annals of Surgery 1997;226(5):662.

4. Frossard JL, Steer ML, Pastor CM. Acute pancreatitis. Lancet 2008;371(9607):143-52.

5. Lippi G, Valentino M, Cervellin G. Laboratory diagnosis of acute pancreatitis: in search of the Holy Grail. Crit Rev Clin Lab Sci 2012;49(1):18-31.

6. McFadden DW. Organ failure and multiple organ failure in pancreatitis. Pancreas 1991;6(1):S37-43.

7. Buchler M, Malfertheiner $\mathrm{P}$, Schadlich $\mathrm{H}$, et al. Role of phospholipase A2 in human acute pancreatitis. Gastroenterology 1989;97(6):1521-6.

8. Hotz J. Konservative therapie der akutenpankreatitis. Chir Gastroenterol 1988;4:59-65.

9. Becker V. Pathological anatomy and pathogenesis of acute pancreatitis. World J Surg 1981;5(3):303-13.

10. Choi TK, Mok F, Zhan WH, et al. Somatostatin in the treatment of acute pancreatitis: a prospective randomized controlled trial. Gut 1989;30(2):223-7.

11. Usadel KH, Uberla KK, Leuschner U. Treatment of acute pancreatitis with somatostatin: results of the multicentre double-blind trial (APTS-Study). Dig Dis Sci 1985;30:992.

12. D'Amico D, Favia G, Biasiato $R$, et al. The use of somatostatin in acute pancreatitis-results of a multicenter trial. Hepatogastroenterology 1990;37(1):92-8.
13. Limberg B, Kommerell B. Treatment of acute pancreatitis with somatostatin. N Engl J Med 1980;303(5):284.

14. Uhl W, Buchler MW, Malfertheiner P, et al. A randomised, double blind, multicentre trial of octreotide in moderate to severe acute pancreatitis. Gut 1999;45(1):97-104.

15. Uhl W, Anghelacopoulos SE, Friess $\mathrm{H}$, et al. The role of octreotide and somatostatin in acute and chronic pancreatitis. Digestion 1999;60(2):23-31.

16. Kitagawa $M$, Naruse $S$, Ishiguro $H$, et al. Pharmaceutical development for treating pancreatic diseases. Pancreas 1998;16(3):427-31.

17. Tenner S, Baillie J, DeWitt J, et al. American college of gastroenterology guideline: management of acute pancreatitis. Am J Gastroenterol 2013;108:1400-15.

18. Banks PA, Bollen TL, Dervenis C, et al. Classification of acute pancreatitis-2012: revision of the atlanta classification and definitions by international consensus. Gut 2013;62(1):102-11.

19. Buchler $\mathrm{M}$, Malferthieiner $\mathrm{P}$, Uhl $\mathrm{W}$, et al. Gabexate mesilate in human acute pancreatitis. Gastroenterology 1993;104(4):1165-70.

20. Binder M, Buichler MW, Uhl W, et al. Octreotide in the treatment of acute pancreatitis: results of anunicentric prospective trial with three different octreotide dosages. Lang Arch Chir Suppl Chir Forum 1993;233-8.

21. Jenkins SA, Berein A. Review article: the relative effectiveness of somatostatin and octreotide therapy in pancreatic disease. Aliment Pharmacolher 1995;9(4):349-61.

22. Greenberg R, Haddad R, Kashtan H, et al. Continuous intravenous octreotide treatment for acute experimental pancreatitis. Digestion 1999;60(2):125-31.

23. Buchler M, Binder M, Friess H. Role of somatostatin and its analogues in the treatment of acute and chronic pancreatitis. Gut 1994;35(3):S15-9.

24. Carballo F, Dominguez E, Femrndez-Calvet L, et al. Is somatostatin useful in the treatment of acute pancreatitis? A metaanalysis. Digestion 1991;49:12-3.

25. Toskes PP, Forsmark CE, DeMeo MT, et al. A multicenter controlled trial of octreotide for the pain of chronic pancreatitis. Pancreas 1993;8:774.

26. Schwedes U, Althoff $\mathrm{PH}$, Klempa I, et al. Effect of somatostatin on bile-induced acute haemorrhagic pancreatitis in the dog. Horm Metab Res 1979;11(12):655-61.

27. Jenkins SA, Barter JN, Day DW, et al. The effects of somatostatin and SMS 201-995 on experimentallyinduced pancreatitis and endotoxaemia in rats and on monocyte activity in patients with cirrhosis and portal hypertension. Klin Wochenschr 1986;64(7):100-6.

28. Zhou H, Gao J, Zou D, et al. Effect of octreotide on enteric motor neurons in experimental acute necrotizing pancreatitis. PLoS ONE 2012;7(12):e52163. doi:10.1371/journal.pone.0052163.

29. Guler O, Akturan S, Kisli E, et al. Acute pancreatitis, bacterial translocation, and different octreotide regimens: an experimental study. Surg Today 2009;39(10):876-83. 